\title{
Allende mi abuelo Allende: un documental sobre los silencios y las memorias familiares
}

\author{
Natacha Scherbovsky \\ Universidad Nacional de Rosario (UNR, \\ Argentina).
}

Allende mi abuelo Allende (2015) comienza con una secuencia de fotos en blanco y negro en donde vemos pasar lentamente las imágenes reconocidas del presidente que llevó adelante el proyecto de la vía chilena al socialismo. Sin embargo, mientras avanza esta secuencia se escuchan fragmentos de entrevistas que nos introducen en un mundo familiar en donde lo que se intenta es poder hablar no ya de Salvador Allende sino del "Chicho»: de ese abuelo, esposo, padre que también fue. De esta manera, escuchamos la voz de Marcia Tambutti, directora del documental, que desde su lugar de nieta pregunta: «Abuela ¿̨usted imaginó cómo sería su vida cuando se casó con el Chicho?». Inmediatamente después le pre- gunta a su primo: «¿Qué cosas te contaba tu mamá del Chicho?» y a su tía le pide que le cuente sobre las fotos que guarda de su padre. La necesidad de Marcia por saber quién era su abuelo se enfrenta con las respuestas de su abuela,de su tía y luego de su madre quienreconoce, entre risas, que cuando Marcia les pregunta se ponen como «arańas». Es decir, se resisten hablar del Chicho, porque el dolor y la angustia vuelve a emerger con su recuerdo.Las resistencias, así como los largos silencios y las incomodidades que se escuchan en esta primera secuencia, moldean la película. Pero Marcia insiste en atravesarlos paratransformar la imagen fija de los afiches y las fotos de Allende en una imagen viviente de su abuelo. 
Marcia Tambutti luego de vivir diecisiete años en México, lugar que la recibió después del destierro los días siguientes al golpe de Estado en Chile (1973-1989) y de un tiempo de vivir en Inglaterra, regresa a su país natal luego de 35 ańos para llevar a cabo su primer proyecto documental. La directora,como afirma en la película en voz en off, se encontraba lista para hablar sobre ese pasado doloroso $\mathrm{y}$ trágico, pero no estaba segura que su familia lo estuviera.

Por eso, de acuerdo con sus propósitos, lleva adelante una investigación indagandoen su propio mundo familiar. Utiliza las fotografías y videos como metodología para elicitar recuerdos, para evocar la memoria sobre el Chicho y cómo se relacionaba con su abuela "Tencha», con su tía «Tati», con sus nietas y nietos. De este modo va conociendo cuáles eran las actividades de su abuelo, sus gustos, sus formas de divertirse, de pasar las vacaciones. $Y$ así va construyendo una cotidianeidad pasada.

A través de entrevistas con sus primos Maya y Alejandro, con su madre Isabel, su tía Carmen Paz, su abuela Tencha, su hermano Gabriel, así como a través del trabajo de archivo con fotos familiares, videos y audios, va hilvanando un relato que busca construir la imagen de su abuelo, pero que también va más allá de Allende, como lo indica el nombre del documental. Más allá de Allende está su familia y cómo lo recuerda, cómo se vincula con su figura, con el pasado. Están los silencios, los tabúes, los secretos. Pero también está la posibilidad de volver hablar, de mirar juntos las fotografías, las imágenes, de discutir, de recordar anécdotas, de reír, de comentar sueños y miedos. A la directora le importa,según sus palabras, «retratar ese forcejeo cariñoso entre mi familia y yo. O esta tensión o ese tratar de acercarse, ejercitar memoria, recobrar historias. En el fondo traerlo de vuelta. Yo decía yo quiero a mi abuelo devuelta y de vuelto (...) lo quiero sacar de este estado latente y lo quiero latiente» (Fuga de Tinta, 4/8/15).

Más allá de Allende está la «Tati», la hija revolucionaria, como se la presenta en el documental. Beatriz, militante del Partido Socialista, fue una de las secretarias de Allende y de las personas más cercanas a él. Se recupera su historia, sus momentos de alegría durante los años de gobierno de la Unidad Popular (1970-1973), pero también sus tristezas, sus fragilidades, las tensiones vividas luego de la muerte de su padre y su exilio en Cuba.Sus hijos se atreven a volver a hablar sobre ella. Por medio de fotos, de videos y de los testimonios de su hermana Isabel, Marcia intenta acercarse a su tía, saber más sobre ella, sobre sus vivencias en Cuba y finalmente sobre su suicidio.

Entonces, más allá de Allende están también los suicidios como marca familiar. Como señala la directora en el documental «sin desearlo Chicho abrió 
en mi familia una posibilidad que normalmente está cerrada». Se abordan con fotos y testimonios, primero el suicidio de Allende, luego el de su tía Tati y el de Laura, la hermana del Chicho. Aunque Marcia no habla del último suicidio, el de su hermano Gabriel, a quien vemos en varias escenas del documental, conversando con la directora, llorando juntos, agarrados de la mano. Solo nos enteramos al final, cuando en las placas negras se lee que la película está dedicada a él y a su abuela Tencha. Entonces, se pone de manifiesto el dolor y la pena que implican hablar de ellos, de sus decisiones de muerte. En una escena paradigmática en la cual Maya, la prima de Marcia, le regala a su abuela Tencha una secuencia fotográfica en la que se ve en una foto a Allende junto a su hija Tati caminando y en la otra dándose un abrazo en la calle. Tencha no puede verla, se pone incómoda y quiere que dejen de filmar. Se expresa, entonces, la dificultad para ver, para verlos, la resistencia y la defensa generada para evitar ese dolor.

En este relato íntimo, familiar, donde la primera persona es la voz del documental, también se escuchan las voces de amigos y conocidos de Allende que aportan informacióntanto como figura política-pública como en sus relaciones amistosas, amorosas, familiares. Solo escuchamos sus testimonios,sus imágenes no aparecen. Por lo que entendemos que la decisión de la directora fue reservar las imágenes para su familia como protagonistas de la historia.

Como plantea María Luisa Ortega (20Io) cuando señala las características de los documentales contemporáneos, en Allende mi abuelo Allende la directora, en tanto sujeto, se va construyendo a sí misma a medida que va transcurriendo el documental. Ya que la necesidad de hablar con sus primos, hermano, tía, y su madre, de conocer a su abuelo a través de sus relatos, es también un modo de conocerse a sí misma y a los otros con su abuelo. Es una reflexión, también, por su propia identidad.

Esta historia personal, la necesidad de hablar, de romper silencios familiares que quedaron después de la dictadura militar en Chile, de volver a reflexionar sobre la identidad, para Marcia Tambutti (Fuga de Tinta, 4/8/15)se relaciona con otras historias familiares latinoamericanas que también vivieron/sufrieron los golpes de Estado. En este sentido, la experiencia personal es también social y se enmarca en la lucha de toda una generación que busca reconstruir su historia, saber quiénes fueron sus padres y abuelos, que sigue reclamando por la verdad, la memoria y la justicia.

La disputa por la memoria se pone de manifiestoen tanto «Allende mi abuelo Allende» representa una de las pocas películas que centran su relato en el primer presidente marxista en Chile. Anteriormente solo existía el documental Salvador 
Allende (2004) dirigido por Patricio Guzmán. Pero en el mismo año de estreno del documental de Marcia Tambutti se estrena la película de ficción Allende en su laberinto (2015), dirigida por Miguel Littín. La exhibición y circulación de estos filmes permiten quebrar ciertos «olvidos», recuperar la figura de Salvador Allende, los proyectos políticos/sociales que llevó adelante la Unidad Popular durante los tres ańos de gobierno, la cotidianeidad de una época, que 17 años de dictadura militar intentaron borrar, silenciar, destruir.

Allende mi abuelo Allende fue reconocido con el Premio Ojo de oro al mejor documental en el Festival de Cine de Cannes 20I5 y con el Premio del Público en SANFIC 20I5. En la primera semana de estreno en Chile asistieron 5500 espectadores. En este sentido, la necesidad de Marcia Tambutti de volver a su abuelo un personaje latente y viviente pudo concretarse, reconocerse y valorarse. Tantos los espectadores chilenos comoextranjerospudieron acercarse a Allende, no ya en blanco y negro sino en color, con sueños, recuerdos, amores, miedos, dolores y alegrías. Lo vieron descansando en un sillón, disfrutando del mar, bailando con Tencha, jugando con sus hijas, abrazando a sus nietas, actuando en una obra teatral entre amigos, discutiendo en actos políticos, escucharon su voz, vieron su imagen de cuerpo entero. Porque, más allá de Allende, estaba el Chicho.

Referencias bibliográficas

- ORTEGA, M. (2010). En torno a las nuevas tendencias expresivas en el documental contemporáneo. Cine Documental, (1). Recuperado de: http://revista.cinedocumental.com.ar/1/ teoria_02.html

Fuentes periodísticas

- TheClinic: Allende mi abuelo Allende' supera 5.500 espectadores en su primera semana. Publicado el 11/09/2015. Disponible en: https://www.theclinic.cl/2015/09/11/allende-mi-abueloallende-supera-5-500-espectadores-en-su-primera-semana/

Entrevista

- Entrevista a Marcia Tambutti. Fuga de Tinta. Publicado 4/08/2015. Disponible en: https://archive.org/details/150904002 